


\title{
Usage and Effects of Algaecide in Kurtboğazı Dam Lake
}

\section{Kurtboğazı Baraj Gölü’nde Algisit Kullanımı ve Etkileri}

\author{
Nuri Kali*, Mehmet Güngör \\ T. C. Ankara Büyükşsehir Belediyesi, Ankara Su ve Kanalizasyon Işsleri Genel Müdürlüğü \\ nurikali@aski.gov.tr (https://orcid.org/0000-0001-5739-1469),mehmetgungor1@aski.gov.tr \\ (https://orcid.org/0000-0002-6689-9288) \\ Received Date: 28.11.2019, Accepted Date: 03.11.2020 \\ DOI:10.31807/tjwsm.652315
}

\begin{abstract}
In recent years, the increased density and incidence of cyanobacteria, also known as blue-green algae, in water resources has become a growing global problem in consequence of the increasing temperature associated with climate change. The growth of cyanobacteria in dam lakes causes algae blooms and deteriorates water quality. Since it contains Methyl-Isoborneol, Geosmin and toxins, taste and odour problems in water occur and those threatens public health. Rising density of algae causes an increase in the total amount of organic carbon in water, which increases the amount of disinfection by-products. In this study, algae control applications were performed during the summer period kesin tarih parantez içinde verilmelidir. The water samples were taken before and after the algaecide application, and total organic carbon, $\mathrm{pH}$, chlorophyll- $a$, dissolved oxygen, copper, turbidity, orthophosphate phosphorus and total nitrogen were analysed. In order to calculate the amount and depth of the algaecide application, we determined which cyanobacterial species would be used. Copper ethanolomine is the main constituent of the algaecide so copper contamination in water has been investigated. In general, the density of cyanobacteria in bay and stagnant waters was increase before its application. According to the results of the study, appropriate doses and times are supporters to prevent algae blooms and to control sudden increases in the number of algae. In accordance with the results of the analysis, permanent copper pollution does not occur at different depths or at different points. However, a small amount of increase in the samples taken during the algaecide effect time can be seen from time to time.
\end{abstract}

Keywords: Algaecide, algae control, Kurtboğazl, algal bloom

$\ddot{O} z$

Son yıllarda, iklim değişikliği ile birlikte görülen sıcaklık artışı sonucunda, su kaynaklarında maviyeşil algler olarak da bilinen siyanobakterilerde artan yoğunluk ve görülme sıklığı giderek büyüyen küresel bir sorun haline gelmiştir. Baraj göllerinde sayısı artan siyanobakteriler aşırı alg artışlarına sebep olmakta su kalitesini bozmaktadır. İçerdiği Metilizoborneol, Geosmin ve toksinler sebebiyle suda tat, koku problemleri yaratmakta ve halk sağlığını tehdit etmektedir. Alglerin yoğunluğunun artması suda toplam organik karbon miktarını artırmakta bu da dezenfeksiyon yan ürünlerinin miktarını artırmaktadır. Çalışmada yaz dönemi boyunca alg kontrolü uygulamaları yapılmıştır. Uygulama öncesi ve sonrasında numuneler alınarak toplam organik karbon, $\mathrm{pH}$, klorofil- $a$, çözünmüş oksijen miktarı, bakır, bulanıklık, ortofosfat fosforu ve toplam azot analizleri yapılmıştır. Uygulanacak algisit miktarı ve derinliğinin hesaplanması için siyanobakteri tür tespitleri yapılmıştır. Kullanılan algisitin

\footnotetext{
* Corresponding author
} 
temel bileşeni bakır etanolomin olduğu için suda oluşması muhtemel bakır kirliliği araştııılmıştır. Genel olarak uygulamadan önce siyanobakterilerin koy ve durgun suların bulunduğu bölgelerde yoğunluğunun arttığı tespit edilmiştir. Çalışmada elde edilen sonuçlara göre uygun doz ve sürede yapılan dozlama aşırı alg artı̧̧larının önüne geçilmesine ve ani artışların kontrol altına alınmasına yardım etmektedir. Analiz sonuçlarına göre farklı derinliklerde ya da farklı noktalarda bakır kirliliği oluşmamakta bununla beraber algisit etki süresinde alınan numunelerde zaman zaman az miktarda artış görülebilmektedir.

Anahtar kelimeler: Algisit, alg kontrolü, Kurtboğazı, aşırı alg artışı

\section{Introduction}

Dam lakes are artificial lakes, built on rivers for the purposes of electricity generation, drinking water supply, irrigation, fishery, flood control and recreation, and also they are the places, formed by a barrier structure for the accumulating water in basin. These lakes can be narrow, long or branched. Dam lakes are different from natural lakes due to their features such as high flow rate, the presence of suspended solids in the entering water, short water resilience. Due to being larger water collection basin, they are affected by pollution in the basin more than natural lakes (Demir \& Atay, 1999).

In recent years, cyanobacteria proliferate rapidly in lakes and dams, which are particularly rich in nutrients such as nitrogen and phosphorus, and thus cause poor water quality. In case of overgrowth, fish death occurs due to the depletion of oxygen in the water or toxins to the environment as a result of algal blooming. In addition, some cyanobacteria can secrete cyanotoxins, which are very dangerous chemicals for human and environmental health. In particular, Geosmin, and 2-methylisoborneol (2MIB) produced by cyanobacteria, is the main cause of taste and odour degradation in water, characterized by soil and mouldy odours. The removal of these chemicals in treatment plants is difficult and costly. Algal blooms make water treatment difficult and causes undesirable taste and odour formation in water. Algae that cannot be processed in water release trihalomethanes and some carcinogenic products as a result of chlorination (Kotak et al., 1993).

Cyanobacteria are prokaryotic organisms with no real nuclei, membrane-bound organelles and plastids (Cirik \& Cirik, 2004). The blue-green appearance of algae is due to the covering of chlorophyll pigment by phycocyanin, phycoerythrin and other pigments (Rinehart et al., 1994). Since there is no nuclear membrane, the DNA and pigment substances are dispersed in the cytoplasm. Cell wall is cellulose and pectin. The substitute food substance is glycogen, cyanophycin and volitin proteins instead of starch (Chorus \& Bartram, 1999). Many types of cyanobacteria are aerobic phototrophs, but some also show heterotrophic properties. Cell shapes of 
cyanobacteria are single, filament or colony-shaped (Cirik \& Gokpinar, 1993). Some species of cyanobacteria develop adherent to the surface, while some species are scattered throughout the water. Various factors such as water temperature, sunlight, the presence of high nutrients, grazing, and climate are effective in the proliferation of cyanobacteria (Anonymous, 2010). Some types of cyanobacteria contain toxic substances. According to their chemical structures, cyanotoxins fall into several main groups: peptides, heterocyclic compounds (alkaloids) or lipidic compounds (Sivonen \& Jones, 1999).

There are 46 species of cyanobacteria that cause toxic effects in vertebrates (Sivonen \& Jones, 1999). Cyanotoxins cause many diseases in humans such as liver cancer, gastroenteritis, respiratory system abnormalities, nausea, vomiting, fever flu-like symptoms, sore throat, ear and eye irritation, rash, abdominal pain, lung consolidation, kidney and liver damage (Qin et al., 2007; Miller \& Tisdale, 1931; Sivonen \& Jones, 1999).

The source of the first reported cyanobacterial gastroenteritis was the Ohio River in 1931 and later on children were poisoned considerably due to an increase in Microcystis spp. in a water tank in Zimbabwe (WHO, 2003). In Sweden, it was reported that in 1994, symptoms like nausea, vomiting, diarrhea, muscle cramps were observed in 121 out of 304 people in a sugar factory as a result of the use of untreated river water containing MCYST from Plantktothrix agardhii (Falconer, 2001). 117 patients, treated at a hemodialysis center in Brazil, were exposed to toxins in water used for dialysis, liver failure was detected in 100 patients and 56 of them were died. (Azevedo et. al., 2002).

In this study, the effects and efficiency of algaecide application in Kurtboğazı Dam were investigated. We expect that algae control is going to reduce the amount of odor and toxin in water treatment plants. It is also expected to prevent possible algae blooms. In this study, it is aimed to find the way of preventing possible algal blooms in Kurtboğazı Dam. Algae control is important issue to have better quality drinking water. This study was conducted to develop methods and methodology for algae control in drinking water sources

\section{Material and Method}

Kurtboğazı is a dam lake, located at the northwest edge of Ankara and far away $47 \mathrm{~km}$ from Ivedik Treatment Plant. It was constructed between 1963 and 1967 for supplying drinking water of Ankara. Its maximum water volume is 92.000.000 
$\mathrm{m}^{3}$. The creeks, namely Bahtıl1, Mera, Kınık, Pazar, Uzunöz, Bostan, Kayıcık, Batak, İğmir, Kirazlı, Eneğim and Karaboya feed the Lake, and it is also used for a recreational area (Figure 1).

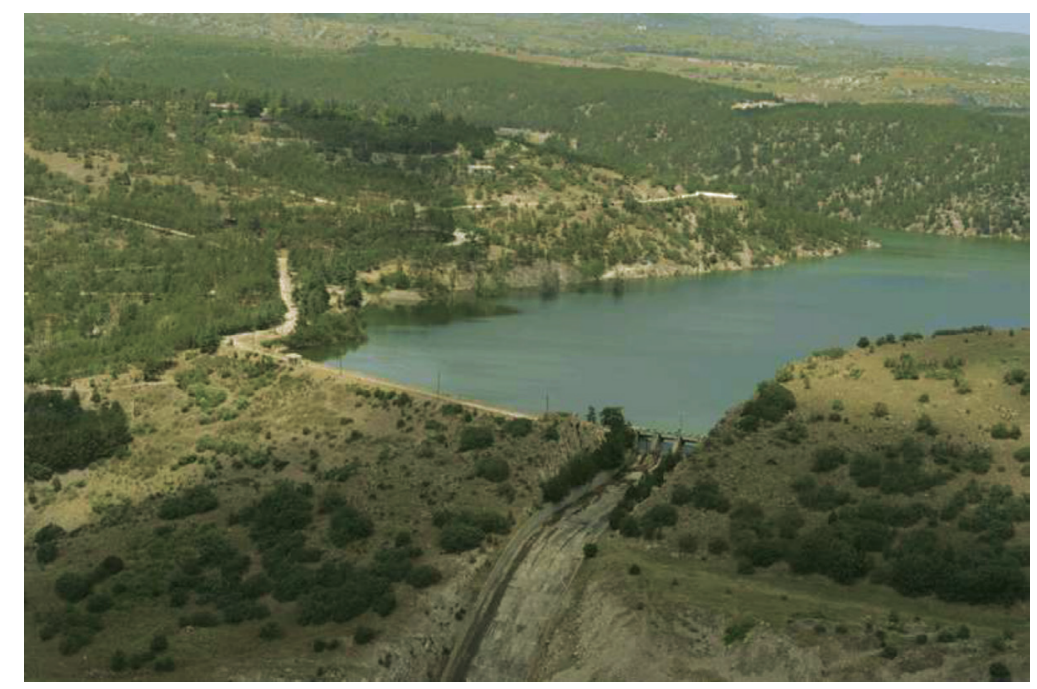

Figure 1. Kurtboğazı Dam Lake.

In this study, TOC, chlorophyll- $a$, dissolved oxygen concentration, $\mathrm{pH}$, water temperature were measured and cyanobacteria species were determined before and after algaecide application in Kurtbogazi Dam Lake.

Dissolved oxygen concentration, $\mathrm{pH}$, and water temperature were measured with WTW 3320 field-type equipment. Hach DR 6000 model spectrophotometer was used for chlorophyll- $a$ measurements. TOC measurements and chemical analyses of ortho phosphatephosphorus, copper, total nitrogen, total organic carbon, turbidity, were performed in Accredited Laboratory of ASKI General Directorate. TOC analyzes were performed according to SM 5310B standards. Copper analyzes were performed according to EPA 200.8 standards. Total nitrogen analyzes were performed according to ISO 29441 standards. Chlorophyll- $a$ analyses were performed according to SM $10200 \mathrm{H}$ standards. Orthophosphatephosphorus analyzes were performed according to TS EN ISO 15681-2 standards.

Turbidity measurements were obtained by the nephelometric method using a HACH $2100 \mathrm{~N}$ Turbidimeter with turbidity units (NTUs). Plankton net was used to take samples for species determination. Plankton net hauled both vertically and horizontally. 
Algicide application was planned to be routinely once a week. Application have been carried out starting from 300 meters away from the water intake structure. Algaecide containing copper ethanolamine complex, which is known to be not harmful to fish and aquatic organisms with a residence time for 14 days, was selected. Algicide was used by diluting at a rate of $1 / 10$. Application was made on between 9 and 29 August.

Considering the residence time, it was predicted that $400 \mathrm{~kg}$ algaecide should be consumed weekly. The total amount of algaecide to be used was calculated as the volume of the application area. $0.3 \mathrm{ppm}$ copper ethanolamine was applied in a square meter section.

At the end of the summer season, algal density increased more than predicted in the last two weeks of August and the weekly dosing of algaecide was increased from $400 \mathrm{~kg}$ to $700 \mathrm{~kg}$. After 15 August, chlorophyll- $a$ value began to increase. Algal density was increased outside the application area. The volumes of these sections were calculated and algicide dosed.

The boat used in the application had a length of $4.90 \mathrm{~m}$ and a $20 \mathrm{hp}$ engine. There was one tank with a capacity of $300 \mathrm{lt}$ on the boat. In order to make dosing into the water, a 3-meter-long installation system was built from the tank to the outside on both sides of the boat. In the filling of the tank, a pump system powered by electricity was used. Rechargeable batteries were used as electrical sources. The application was made by an aquaculture engineer and a technician.

\section{Results}

Cyanobacteria can be seen at different depths in the water body. Some types of cyanobacteria can be found in the upper layers of water, while some types of cyanobacteria can form surface scums (Microcystis, etc.). On the other hand, some species can be found in the thermocline layer (Albay et al., 2016). Therefore, it is important to determine the dominant species by taking samples from water column before the algicide application. The implementation strategy should be determined according to the identified species.

In this study, we ascertained that cyanobacteria was found more in stagnant and coastal waters than main water body. The route of application is shown in figure 4. Algae produces energy through photosynthesis and takes nutrients when photosynthesis is high. Because of that sunny days were preferred for algicide dosing and it was performed during the hours of a large amount of sun light. 
Nuri Kali, Mehmet Güngör / Turkish Journal of Water Science \& Management 4 (2) (2020) / $162-177$

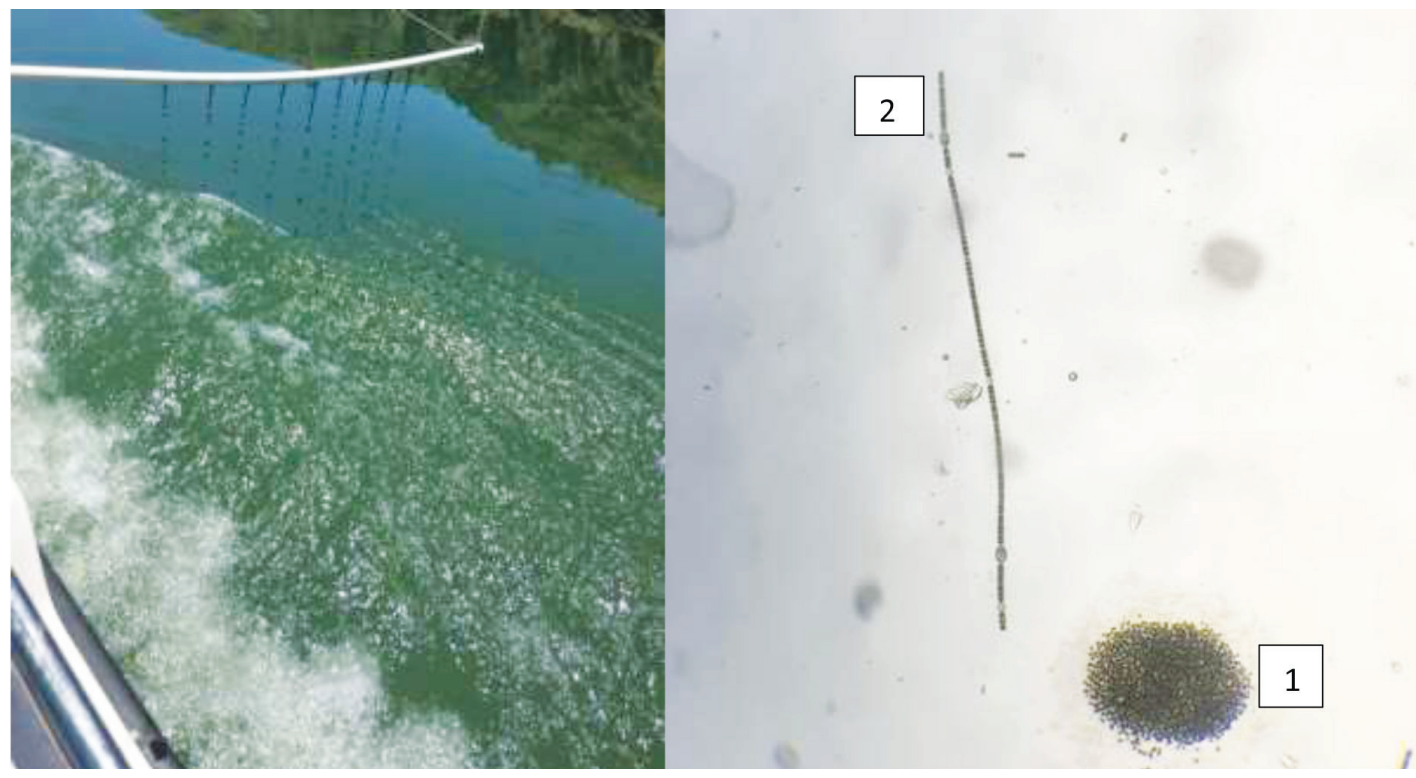

Figure 2. Algicide application.

Figure 3. M. aeruginosa (1), D. planctonicum (2).

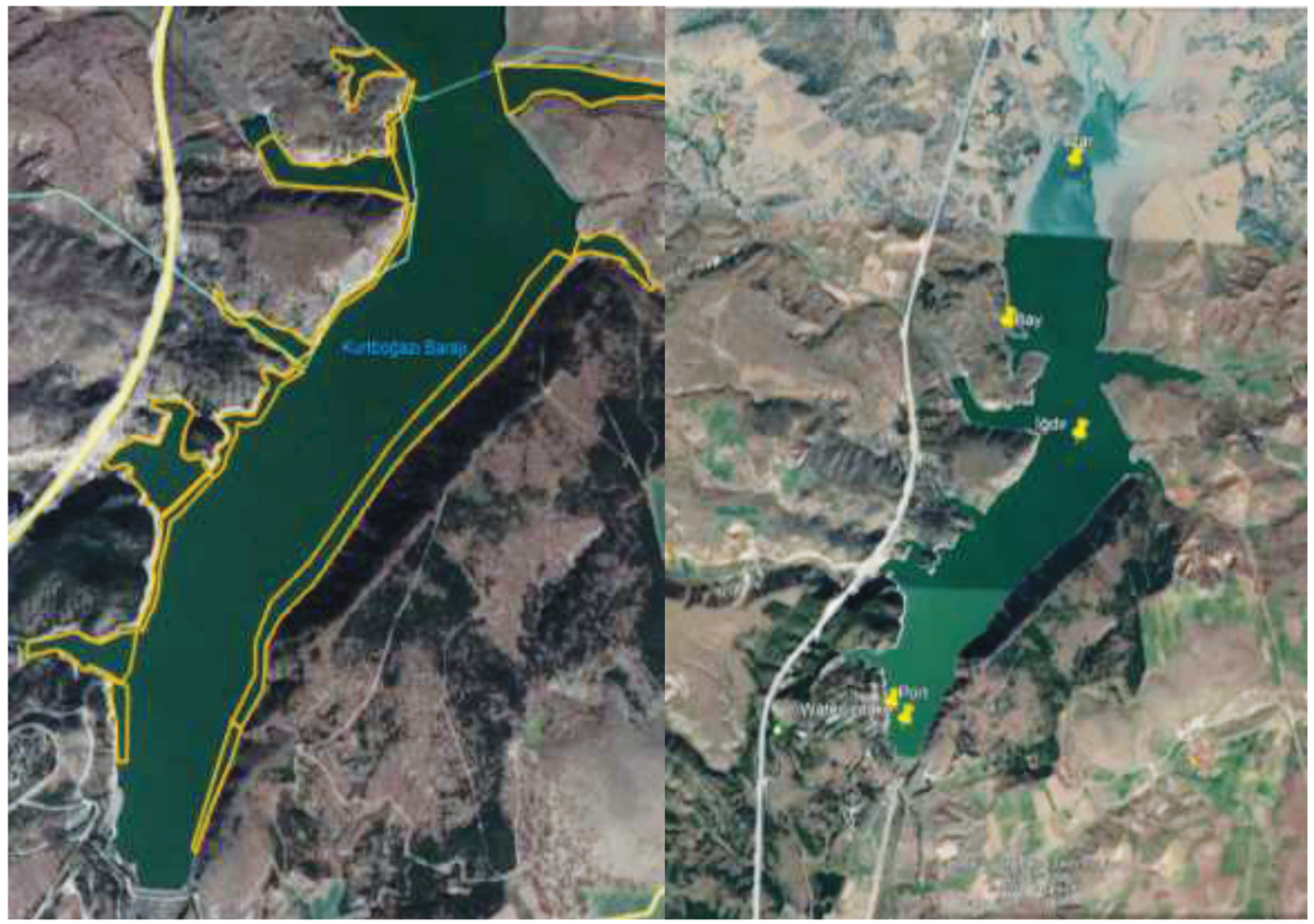

Figure 4. Application area and the sampling sites. 
Five sampling points were selected and samples were taken on August 8 and 15 for the study: 1) Bay point is one of its stagnant section which had the highest algae concentration during the summer of 2019, 2)Pazar point, its stream section, was particularly rich in nutrients, 3) İğdir point, representative of its main section, was chosen to see the changes across the dam lake, 4) Water intake point represents the raw water coming to the İvedik Water Treatment Plant and 5) The point was selected as the representative of the highest water flow. Figure 4 shows the sampling points.

During the studies made for different periods of the summer 2019, Microcystis aeruginosa and Dolichospermum planctonicum were identified as dominant species in the samples.

Table 1

Analysis Results for August 2019

\begin{tabular}{llllllll}
\hline Station & Date & $\begin{array}{l}\text { Copper } \\
\mathrm{mg} / \mathrm{L}\end{array}$ & $\begin{array}{l}\text { Turbidity } \\
\text { NTU }\end{array}$ & $\begin{array}{l}\text { Ortho } \\
\text { Phosphate } \\
\text { Phosphorus } \\
\mathrm{mg} / \mathrm{L}\end{array}$ & $\mathrm{pH}$ & $\begin{array}{l}\text { Total } \\
\text { Nitrogen } \\
\mathrm{mg} / \mathrm{L}\end{array}$ & $\begin{array}{l}\text { Total } \\
\text { Organic } \\
\text { Carbon mg/L }\end{array}$ \\
\hline \multirow{2}{*}{ Ĭğdir } & 08.08 .2019 & $<0,003$ & 4,50 & $<0,02$ & 9,3 & 1,09 & 3,60 \\
& 15.08 .2019 & 0,012 & 5,00 & 0,03 & 9,3 & 0,70 & 3,59 \\
& 08.08 .2019 & 0,007 & 95,00 & $<0,02$ & 9,5 & 2,25 & 15,60 \\
Bay & 15.08 .2019 & 0,020 & 6,90 & 0,04 & 9,2 & 0,67 & 3,97 \\
& 08.08 .2019 & 0,003 & 4,70 & $<0,02$ & 9,1 & 1,26 & 3,45 \\
Port & 15.08 .2019 & 0,011 & 8,10 & 0,02 & 9,4 & 0,59 & 3,69 \\
& 08.08 .2019 & $<0,003$ & 6,30 & $<0,02$ & 9,5 & 1,37 & 3,76 \\
Pazar & 15.08 .2019 & 0,011 & 5,80 & 0,04 & 8,6 & 0,61 & 3,69 \\
& 08.08 .2019 & $<0,003$ & 4,80 & $<0,02$ & 9,0 & 1,49 & 4,65 \\
Water intake & 15.08 .2019 & 0,012 & 7,70 & 0,05 & 9,6 & 0,75 & 3,59 \\
\hline
\end{tabular}

The first algaecide application was made on August 9 and the others were made respectively on $15^{\text {th }}, 23^{\text {rd }}$ and $29^{\text {th }}$ of August. After algaecide application, TOC values in the reservoir generally began to decrease and this decrease was higher in coastal areas and bays. 
Composite samples were taken from 5 points (İğdir, Bay, Port, Pazar and Water intake) for chlorophyll- $a$ analysis, and the analysis results are given in Table 2.

Table 2

Chlorophyll-a Analysis Results

\begin{tabular}{ll}
\hline Date & Chlorophyll- $a \mu \mathrm{g} / \mathrm{L}$ \\
\hline 08.08 .2019 & 59,1 \\
12.08 .2019 & 47,6 \\
15.08 .2019 & 89,4 \\
24.08 .2019 & 10,2 \\
26.08 .2019 & 20,1 \\
28.08 .2019 & 35,9 \\
31.08 .2019 & 26,4 \\
\hline
\end{tabular}

According to the results, the algae concentration in water decreased in 5-9 days after the application. Figures 5 and 6 show the situation of the water before and after application at the bay point and port point.

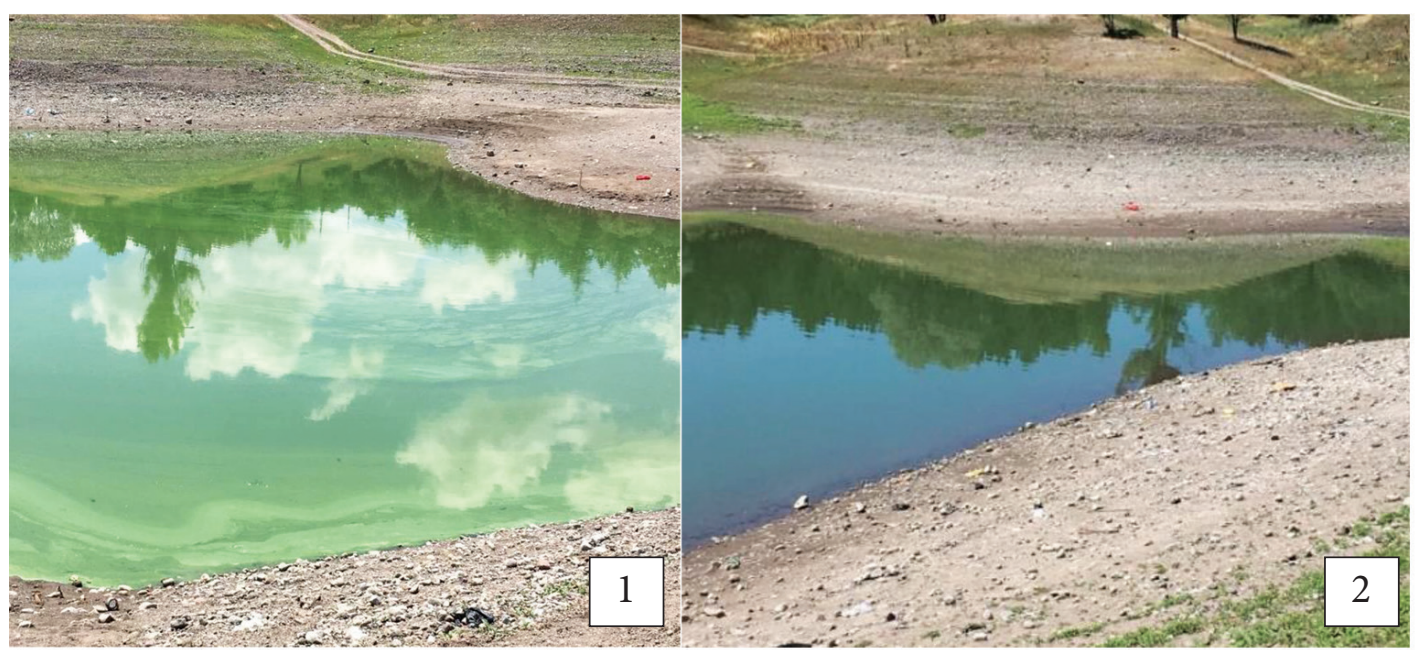

Figure 5. The changes of algae abundance in bay point before (1) and after (2) application. 


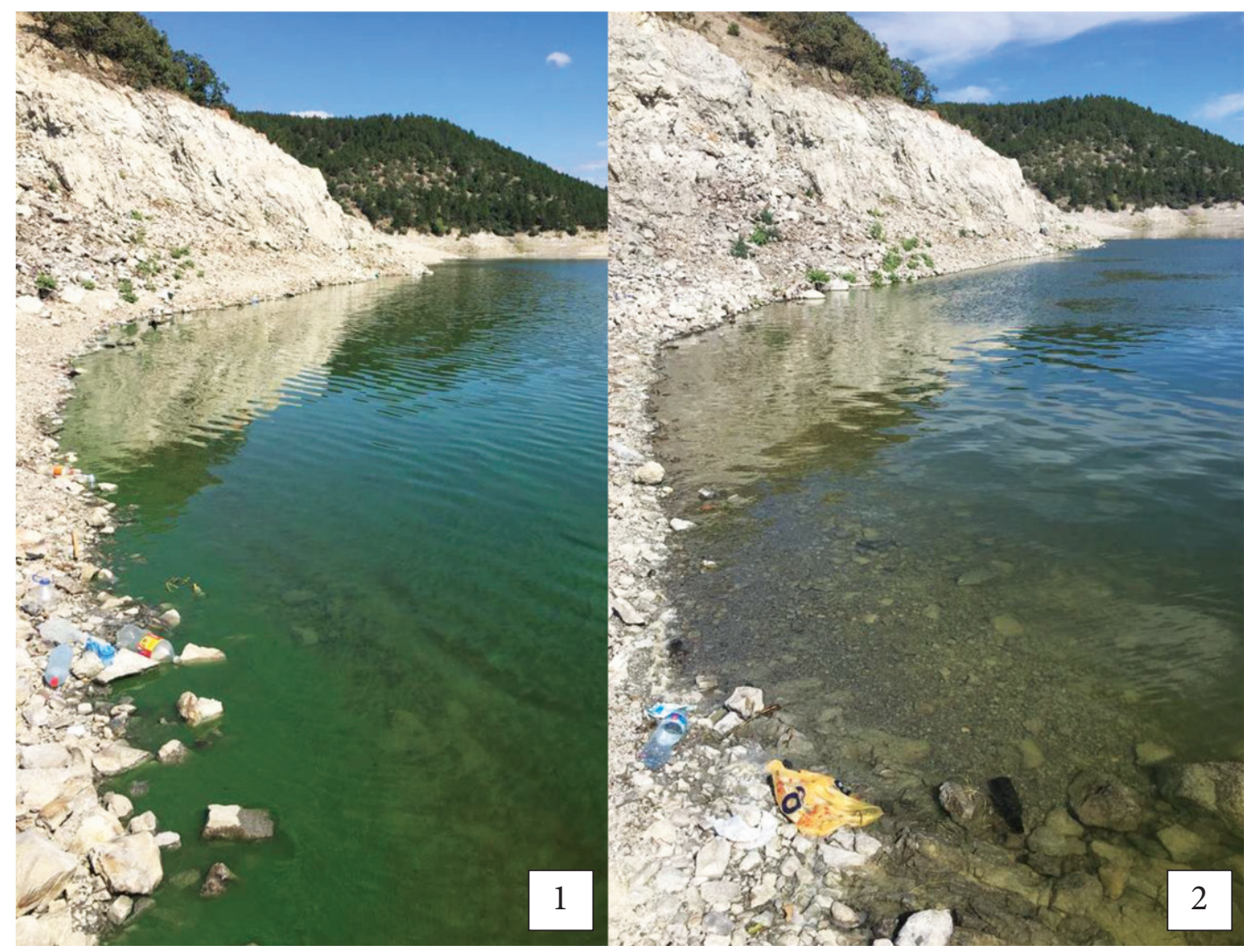

Figure 6. The changes of algae abudance in port point before (1) and after (2) application.

In order to see the effects of the algaecide application, samples were taken from different depths of the dam lake, and the effects of the application on water quality were investigated. Table 3 shows the copper concentration, turbidity, ortho phosphate phosphorus, $\mathrm{pH}$, total nitrogen and total organic carbon through the water column.

Algaecide used in the study consisted of copper ethanolamine complex. The analysis were carried out to determine the changes in the amount of copper as a result of the application in the reservoir. Table 4 shows the changes in the copper concentrations in the raw water in the İvedik water treatment plant. 
Table 3

Changes of Water Quality Parameters Depending on Depth

\begin{tabular}{llllllll}
\hline Station & Date & $\begin{array}{l}\text { Copper } \\
\mathrm{mg} / \mathrm{L}\end{array}$ & $\begin{array}{l}\text { Turbidity } \\
\text { NTU }\end{array}$ & $\begin{array}{l}\text { Ortho } \\
\text { Phosphate } \\
\text { Phosphorus } \\
\mathrm{mg} / \mathrm{L}\end{array}$ & $\mathrm{pH}$ & $\begin{array}{l}\text { Total } \\
\text { Nitrogen } \\
\mathrm{mg} / \mathrm{L}\end{array}$ & $\begin{array}{l}\text { Total } \\
\text { Organic } \\
\text { Carbon } \\
\mathrm{mg} / \mathrm{L}\end{array}$ \\
\hline \multirow{2}{*}{ Surface } & 08.08 .2019 & $<0,003$ & 4,80 & $<0,02$ & 9,0 & 1,49 & 4,65 \\
& 26.09 .2019 & 0,012 & 3,40 & - & 8,8 & $<0,10$ & 4,26 \\
\multirow{2}{*}{ Mid (16 m) } & 08.08 .2019 & $<0,003$ & 2,60 & $<0,02$ & 8,2 & 2,21 & 4,34 \\
& 26.09 .2019 & 0,011 & 3,30 & - & 7,8 & $<0,10$ & 4,57 \\
Deep (32 m) & 08.08 .2019 & $<0,003$ & 4,70 & $<0,02$ & 8,2 & 1,44 & 3,40 \\
& 26.09 .2019 & 0,010 & 5,60 & - & 8,0 & $<0,10$ & 4,26 \\
\hline
\end{tabular}

Table 4

Changes of Copper Concentrations in Raw Water

\begin{tabular}{ll}
\hline Date & Copper $\mathrm{mg} / \mathrm{L}$ \\
\hline 01.07 .2019 & 0,005 \\
08.07 .2019 & $<0,003$ \\
16.07 .2019 & $<0,003$ \\
22.07 .2019 & $<0,003$ \\
29.07 .2019 & $<0,003$ \\
05.08 .2019 & $<0,003$ \\
15.08 .2019 & 0,012 \\
19.08 .2019 & $<0,003$ \\
26.08 .2019 & 0,005 \\
02.09 .2019 & $<0,003$ \\
09.09 .2019 & $<0,003$ \\
16.09 .2019 & $<0,003$ \\
23.09 .2019 & 0,012 \\
30.09 .2019 & $<0,003$ \\
07.10 .2019 & $<0,003$ \\
14.10 .2019 & $<0,003$ \\
\hline
\end{tabular}


As shown in Tables 3 and 4, there was a slight increase in the amount of copper after application once a week, however it was still under U.S. Environmental Protection Agency (EPA) limit values. It was observed that copper levels returned to the previous levels in one or two weeks after the application. After application, there is a decrease in the amount of total organic carbon and chlorophyll- $a$.

\section{Discussion and Conclusion}

Albay et al. (2003) reported a significant reduction in the biomass of cyanobacteria in Ömerli Dam Lake. Pascual and Tedesco (2003) studied the Eagle Creek reservoir and detected a reduction in phytoplankton biomass. Mastin et al. (2002) measured responses of Lyngbya from a North Louisiana reservoir and they found $78 \%$ decrease in Lyngbya after application. In our study, we have seen a similar decrease in phytoplankton biomass.

According to the study's results, it was confirmed that dosing to drinking water reservoirs with algicide in appropriate doses at the proper time served to prevent algae blooms and also control sudden increases in the amount of algae. Additionally, the results of the analyses showed that copper pollution didn't occur at different depths or at different points in water column. However, a small increase in the amount of copper was detected at samples which have been taken during the algicide effect duration. It was determined that algicide containing copper ethanolamine prevented algae growth when it was used in appropriate doses at the proper time. However, in order to prevent copper pollution: 1) the properties of the algicide should be well known, 2) water quality parameters should be determined, 3) cyanobacteria species and their properties should be identified. It should be noted that the algicide was a chemical substitute and should be applied after all aspects of the application have been evaluated. 


\section{References}

Albay, M., Akcaalan, R., Aykulu, G., Tufekci, H., Beattie, K. A., \& Codd GA. (2003). Occurrence of toxic cyanobacteria before and after copper sulphate treatment in a water reservoir, Istanbul, Turkey. Algological Studies; 109, 67-78. DOI: 10.1127/1864-1318/2003/0109-0067

Albay, M., Albay, R., \& Ertürk, A. (2016). Yer Üstü Suları ile Yüzme ve Rekreasyon Amacıyla Kullanılan Klyı Sularında Siyanobakteriler için Alarm Seviyelerinin ve Limitlerin Belirlenmesi, Müdahale ve Mücadele Yöntemlerinin Gelişstirilme Projesi. Su Yönetimi Genel Müdürlüğü (in Turkish).

Azevedo, S.M.F.O., Carmichael, W.W., Jochimsen, E.M., Rinehart, K.L., Lau, S., Shaw, G.R., \& Eaglesham, G. K. (2002). Human intoxication by microcystins during renal dialysis treatment in Caruaru, Brazil. Toxicology, 181-182, 441-446.

Anonymous. (2010). Cyanobacteria California Recreational Water Bodies: Providing Voluntary Guidance about Harmful Algal Blooms, Their Monitoring and Public Notification. Retrieved November, 11, 2019 from http://www.karuk.us/karuk/images/docs/wqdocuments/Copco_toxic_ bloom_8-7-07.pdf

Chorus, I., \& Bartram, J. (1999). Toxic cyanobacteria in water: A guide to their public health consequences, monitoring and management. The World Health Organization. Retrieved November,11, 2019 from https://apps.who.int/iris/handle/10665/42827

Cirik, Ş., \& Cirik, S. (2004). Su Bitkileri, Deniz Bitkilerinin Biyolojisi, Ekolojisi, Yetiştirme Teknikleri. Ege Üniversitesi Su Ürünleri Fakültesi Yayınları, 34-38 (in Turkish).

Cirik, S., \& Gökpınar, Ş. (1993). Plankton Bilgisi ve Kültürü. Ege Üniversitesi Su Ürünleri Yayınlarl, 274 (in Turkish).

Demir, N., \& Atay, D. (1999). Kurtboğazı ve Çamlıdere Baraj Göllerinin Fitoplanktonu. X. Ulusal Su Ürünleri Sempozyumu, Cilt II, 577-587.

Falconer, I. R. (2001): Toxic cyanobacteria bloom problems in Australian water: risks and impacts on human health. Phycologia, 40, 228-233.

Kotak, B. G., Kenefick, S. L., Fritz, D. V., Rousseaux, C.G., Prepas, E. E., \& Hrudey, S. E. (1993). Occurence and toxicological evaluation of cyanobacterial sources in Alberta lakes and farm dugouts. Water Research 27(3), 495-506. https://doi.org/10.1016/0043-1354(93)90050-R

Mastin, J. B., Rodgers Jr, J.H., \& Deardorf, T.L. (2002). Risk evaluation of cyanobacteria-dominated algal blooms in a north Louisiana reservoir. Journal of Aquatic Ecosystem Stress and Recovery, 9, 103-114.

Miller, A.P., \& Tisdale, E.S. (1931). Epidemic of intestinal disorders in Charleston, W. Va., occurring simultaneously with unprecedented water supply conditions. The American Journal of Public Health and the Nations Health, 198-200.

Pascual, D.L., \& Tedesco, L.P. (2003). Eagle Creek Reservoir: Responses to Algicide Treatment. Indiana University - Purdue University, Indianapolis, Department of Geology. 
Qin, B., Xu, P., Wu, Q., Luo, L., \& Zhang, Y. (2007). Environmental issues of Lake Taihu, China. In: Qin, B., Liu, Z., Havens, K. (Eds.). Springer, Netherlands.

Rinehart, K. L., Namikoshi, M., \& Choi, B. W. (1994). Structure and biosynthesis of toxins blue-green algae (cyanobacteria). Journal of Phycology, 6, 159-176.

Sivonen, K., \& Jones, J. (1999). Cyanobacterial toxins. In: Chorus I, Bartram J, ed. Toxic cyanobacteria in water. A guide to their public health consequences, monitoring and management. The World Health Organization. Retrived November, 11, 2019 from https://www.who.int/water_sanitation_ health/resourcesquality/toxcyanchap3.pdf?ua $=1$

WHO. (2003). Guidelines for safe recreational water environments. Volume 1: Coastal and fresh waters. Chapter 8: Algae and cyanobacteria in fresh water. Retrived November, 11, 2019 from https://apps.who.int/iris/bitstream/handle/10665/42591/9241545801.pdf;jses 


\section{Extended Turkish Abstract \\ (Genişletilmiş Türkçe Özet)}

\section{Kurtboğazı Baraj Gölü’nde Algisit Kullanımı ve Etkileri}

Baraj golleri, elektrik üretimi, içme suyu temini, sulama, balıkçılık, sel kontrolü ve rekreasyon amaciyla akarsular üzerine inşa edilen ve suyu engelleyerek havzada birikmesini sağlayan yapay göllerdir. Bu göller dar, uzun veya dallanmış yapıda olabilir. Baraj gölleri, yüksek akış hızı, giriş suyunda askıda katı madde varlığı, kısa su değişim süresi gibi özelliklerinden dolayı doğal göllerden farklıdır. Su toplama havzasının daha geniş olması nedeniyle doğal göllere göre havzadaki kirlenmeden daha fazla etkilenirler (Demir \& Atay, 1999).

İklim değişikliği nedeniyle sıcaklığın artmasıyla birlikte son yıllarda mavi-yeşil algler olarak da bilinen siyanobakteriler su kaynaklarında yoğun ve sıklıkla görülmüştür. Alg artışları giderek büyüyen küresel sorunlardan biri haline gelmiştir. Siyanobakteriler özellikle besin elementlerinden olan azot ve fosfor açısından zengin göl ve barajlarda hızla çoğalırlar ve bu nedenle su kaynaklarının kalitesini bozarlar. Çok aşırı çoğalmaları durumunda özellikle sudaki oksijenin tükenmesine veya aşırı alg artışları sonucunda ortama toksin vererek balık ölümlerine neden olurlar. Bazı siyanobakteri türleri ise insan ve çevre sağlığı açısından oldukça tehlikeli kimyasallar olan siyanotoksinleri salgılayabilmektedirler. Özellikle siyanobakterilerin ürettiği 2- metilisoborneol (2-MIB) ve Geosmin sularda tat ve koku bozukluklarının temel nedeni olup sularda topraksı ve küfümsü kokularıyla karakterize edilirler. Bu kimyasalların arıtma tesislerinde giderimi zor ve maliyetlidir.

Siyanobakteriler gerçek çekirdekleri, zar ile çevrili organelleri ve plastidleri olmayan prokaryotik canlılardır (Cirik \& Cirik, 2004). Alglerin mavi yeşil görünümü fikosiyanin ve diğer pigmentlerin fikoeritrin pigmentini örtmesinden kaynaklanmaktadır (Rinehart ve ark., 1994). Çekirdek zarı olmadığından DNA ve pigment maddeleri sitoplazma içinde dağınık halde bulunur. Hücre çeperi selüloz ve pektindir. Yedek besin maddesi nişasta yerine glikojen, proteinlerden siyanofisin ve volitindir (Chorus \& Bartram, 1999). Klorofil-a içerirler. Renkleri mavi-yeşilden kırmızı renge kadar değişim göstermesine rağmen genel olarak mavi-yeşil olduğundan mavi-yeşil algler olarak da adlandırılırlar. Birçok siyanobakteri türü aerobik fototroftur, fakat bazıları heterotrofik özellik de gösterir. Siyanobakterilerin hücre şekilleri tek, filament veya koloni şeklindedir (Cirik \& Gökpınar, 1993). Bazı türleri yüzeylere yapışık olarak gelişirken, bazı türleri su sütununun tamamına dağılmış olarak bulunurlar. Çoğalmasında su sıcaklığı, güneş ışığı, yüksek besin maddesinin bulunması, otlatma, iklim gibi çeşitli faktörler etkilidir (Anonymous, 2010). Kimyasal yapılarına göre, siyanotoksinler birkaç ana gruba ayrılır: peptitler, heterosiklik bileşikler (alkaloidler) veya lipitik bileşikler (Sivonen \&Jones, 1999).

Aşırı alg artışları su arıtımını güçleştirmekte ve suda istenmeyen bir tat ve koku oluşumuna sebep olmaktadır. Suda arıtılamayan algler klorlama sonucu trihalometan ve bazı kansorejen ürünleri açığa çıkarır (Kotak ve ark., 1993).

Çalışmada algisit uygulaması öncesinde ve sonrasında TOC miktarı, klorofil- $a$ miktarı, çözünmüş oksijen miktarı, pH, sıcaklık ölçümleri ve siyanobakteri tür tespiti yapılmıştır.

Seki derinliği ölçümleri seki diski ile yapılmıştır. Çözünmüş oksijen miktarı, pH, sıcaklık ölçümleri wtw multi 3320 saha tipi ölçüm cihazları ile yapılmıştır. Klorofil- $a$ ölçümlerinde Hach 
DR 6000 model spektrofotometre kullanılmıştır. TOC ölçümleri ve kimyasal analizler ASKİ Genel Müdürlüğü'ne bağlı Akredite Laboratuvarında yapılmıştır. Tür tespiti için gerekli numunelerin alınmasında plankton kepçesi kullanılmıştır.

Algisit uygulaması rutin olarak haftada bir kez olmak üzere planlanmıştır. Sulama yapısının 300 metre uzağından başlanarak çalışmalar yapılmıştır. Algisit seçiminde, sucul ortamda yaşayan balık vb. canlılara zararı olmayan ve bakır etanolamin içerikli olanı tercih edilmiştir. Algasit 1/10 oranında seyreltilerek kullanılmıştır.

Uygulamada kullanılan tekne 4,90 m uzunluğunda, 20 hp motora sahiptir. Kullanılan tekne üzerinde 300 lt kapasiteye sahip bir tank bulunmaktadır. Suya dozaj yapılabilmesi için tanktan teknenin her iki yanından dışarısına doğru 3 metre uzunluğunda tesisat sistemi yapılmıştır. Tankın doldurulmasında elektrik enerjisi ile çalışan pompa sistemi kullanılmıştır. Elektrik kaynağı olarak şarj edilebilir aküler kullanılmıştır. Uygulama 2 personel tarafından yapılııştır.

Siyanobakteriler farkı derinliklerde görülebilir. Bazı siyanobakteri türleri yüzeyde tabaka oluşturacak şekilde ( Microcystis vb) bazı siyanobakteri türleri suyun üst tabakalarında dağınık halde bulunabilir. Diğer yandan bazı türler termoklin tabakasında yer alabilirler (Albay ve ark., 2016). Bu sebeple uygulama öncesinde sudan numuneler alınarak baskın türün tespiti önem arz etmektedir. Tespit edilen türe göre uygulama stratejisi belirlenmelidir.

Yapılan çalışma esnasında yaz döneminde farklı zamanlarda 2 farklı tür tespit edilmiştir. Alınan numuneler sonucunda Microcystis aeruginosa, Dolichospermum planctonicum türlerinin baskın olduğu tespit edilmiştir. Buna göre uygulama stratejisi geliştirilmiştir. Su derinliğinin 1 metreye kadar olan bölümü uygulama için dikkate alınmıştır.

Hesaplanan su kütlesine göre etki süresi göz önüne alındığında haftalık 400 kg algasit tüketimi öngörülmüştür. Ancak yaz mevsiminin sonunda 2 haftalık süreç içerisinde yoğunluk artmış olup bu dönemde haftalık doz miktarı 700 kg’a çıkartılmıştır.

Yapılan çalışmada siyanobakterilerin durgun su ve kıyı sularında daha fazla geliştiği ana su kütlesinde bulunma miktarlarının az olduğu tespit edilmiştir. Rota elde edilen verilere göre düzenlenmiş ve Şekil 4' te gösterilmiş̧ir. Ayrıca ana su kütlesi içerisine koruma amaçlı uygulama yapılmıştır. Çalışmada güneşli günler tercih edilmiş olup dozlama güneş ışınlarının yoğun geldiği saatlerde yapılmıştır.

İlk uygulama 9 Ağustos tarihinde yapılmıştır. Diğer uygulamalar ise 15 Ağustos, 23 Ağustos ve 29 Ağustos tarihlerinde yapılmıştır. Numune noktalarından dördü kısmen akıntıya sahip değişken bir su yapısına sahipken bir nokta akıntı alanı dışında kalmakta ve hareketsiz su kütlesinde bulunmaktadır. Elde edilen bulgulara göre TOC değerlerinde genel olarak bir düşüş olmakla beraber bu düşüşün hareketsiz bölümde fazla olduğu görülmektedir.

Yapılan çalışmada elde edilen sonuçlara göre uygun doz ve sürede yapılan dozlama aşırı alg artışlarının önüne geçilmesine ve ani artışların kontrol altına alınmasına yardım etmektedir. Analiz sonuçlarına göre farklı derinliklerde ya da farklı noktalarda bakır kirliliği oluşmamakta, bununla beraber algisit etki süresinde alınan numunelerde zaman zaman küçük miktarlarda artış görülmektedir. 
Nuri Kali, Mehmet Güngör / Turkish Journal of Water Science \& Management 4 (2) (2020) / $162-177$

Bakır etanolamin içeren algisit, uygun doz ve sürede kullanıldığında alg artışının önüne geçtiği tespit edilmiştir. Ancak bakır kirliliği oluşturmaması için kullanılması planlanan algisitin özelliklerinin yanı sıra sudaki siyanobakteri türlerinin ve özelliklerinin iyi bilinmesi, su kalite parametrelerinin tespit edilmesi gerekmektedir. Kullanılacak olan algisitin bir kimyasal olduğu unutulmamalı yapılacak olan çalışmalar tüm yönleriyle değerlendirildikten sonra uygulanmalıdır. 